\title{
BUDAYA KESELAMATAN KERJA DI INDUSTRI KONSTRUKSI: TINJAUAN DAN USUSLAN PENELITIAN DI MASA DEPAN
}

\section{SAFETY CULTURE IN CONSTRUCTION INDUSTRY: A REVIEW AND FUTURE RESEARCH PROPOSAL}

\author{
Ahmad Hidayat Sutawijaya*), Winda Widyanty*1 \\ *) Program Studi Doktor Manajemen, Universitas Mercu Buana \\ Jl. Meruya Selatan No.1, Kembangan, Meruya Selatan, Jakarta Barat 11650, Indonesia
}

\begin{abstract}
This article aims to describe the state-of-the-art in occupational safety culture in the construction industry and propose a future research agenda. A systematic literature review is carried out comprehensively about the study of work safety culture in the construction industry in relation to improving employee performance which has an impact on improving company performance. Previous research has shown work safety culture as a corporate culture that can reduce accident rates and improve safety performance, but there is no research that discusses how the role of work safety culture from the employee's point of view can contribute to improving company performance, especially in high-risk industries such as the construction industry. . In addition, previous research has not revealed the interpretation of work safety culture based on the practice of implementing work safety culture at the employee level in construction companies. Based on the review conducted, eight future research agendas were proposed. This article is believed to be the first to discuss a literature review on work safety culture in relation to improving company performance through the perspective of employees in the construction industry in Indonesia.
\end{abstract}

Keywords: construction industry, safety culture, company performance, state-of-the-art, literature review

\begin{abstract}
Abstrak: Artikel ini bertujuan menggambarkan state-of-the-art dalam budaya keselamatan kerja di Industri konstruksi dan mengusulkan agenda penelitian di masa mendatang. Sistematik literature review dilakukan secara komprehensif tentang studi budaya keselamatan kerja di industri konstruksi dalam kaitannya dengan peningkatakan kinerja karyawan yang berdampak pada peningkatan kinerja perusahaan. Penelitian sebelumnya menunjukkan budaya keselamatan kerja sebagai budaya perusahaan yang dapat menurunkan tingkat kecelakaan dan meningkatkan kinerja keselamatan, namun belum ada penelitian yang membahas bagaimana peran budaya keselamatan kerja dari sudut pandang karyawan yang dapat berkontribusi pada peningkatan kinerja perusahaan terutama di Industri yang berisiko tinggi seperti industri konstruksi. Selain itu, penelitian terdahulu juga belum mengungkapkan intepretasi budaya keselamatan kerja berdasarkan praktik penerapan budaya keselamatan kerja pada level karyawan di perusahaan konstruksi. Berdasarkan tinjauan yang dilakukan, diusulkan delapan agenda penelitian di masa datang. Artikel ini diyakini sebagai yang pertama membahas tinjauan literatur tentang budaya keselamatan kerja dalam kaitannya untuk meningkatkan kinerja perusahaan melalui perspektif karyawan pada industri konstruksi di Indonesia.
\end{abstract}

Kata kunci: industri konstruksi, budaya keselamatan kerja, kinerja perusahaan, state-ofthe-art, kajian pustaka

\footnotetext{
${ }^{1}$ Corresponding author:

Email:winda.widyanty@mercubuana.ac.id
} 


\section{PENDAHULUAN}

Budaya keselamatan kerja telah lama menjadi aspek penting dari budaya perusahaan. Banyak teori yang berkembang tentang budaya keselamatan kerja. Budaya sendiri dapat diartikan sebagai sistem pembagian makna yang dilakukan oleh anggota yang membedakan suatu perusahaan dengan perusahaan lain (Islam et al. 2019). Menurut teori, budaya memiliki empat fungsi: (i) budaya memiliki peran untuk mendefinisikan batas-batas, (ii) sebagai identitas bagi anggota perusahaan, (iii) budaya dapat memfasilitasi komitmen yang lebih besar dari kepentingan individu, (iv) mendorong stabilitas sistem sosial (Margaretha \& Saragih, 2013). Sedangkan budaya keselamatan kerja diartikan sebagai produk yang dihasilkan dari individu, kelompok, sikap, persepsi, serta pola perilaku yang menentukan komitmen dan keterampilan dalam mengelola keselamatan dalam perusahaan. Karena pentingnya, budaya keselamatan kerja harus diterapkan di setiap jenis perusahaan; baik manufaktur maupun jasa terutama di industri konstruksi (de Castro et al. 2017).

Belakangan ini banyak industri konstruksi di seluruh dunia telah menerapkan budaya keselamatan kerja. Survei budaya keselamatan kerja (2020) menunjukkan bahwa penerapan budaya keselamatan kerja dalam industri konstruksi terus meningkat dari tahun ke tahun (Tabel 1). Manu et al. (2018) melaporkan bahwa sebagian besar industri konstruksi di tiga negara di Asia (Malaysia, Vietnam, dan Kamboja) telah menerapkan budaya keselamatan kerja. Sementaraitu, van Ooijen etal.(2019)menyatakan bahwa hampir seluruh perusahaan konstruksi di dunia telah menerapkan budaya keselamatan kerja yang diwujudkan kedalam sistem manajemen keselamatan kerja yang merujuk pada standar internasional Occupational Safety and Health Administration (OSHA). Namun di Indonesia, hanya 296 dari 160.576 perusahaan konstruksi yang telah menerapkan budaya keselamatan kerja (Sucofindo, 2019).
Penelitian tentang budaya keselamatan kerja yang dilakukan selama ini terbatas pada kajian teknis dan belum mengkaji secara strategis tentang bagaimana budaya keselamatan kerja dapat berperan dalam meningkatkan kinerja perusahaan konstruksi di Indonesia (Machfudiyanto et al. 2017; Oswald et al. 2018; Schwatka et al. 2016; Sutawijaya \& Nawangsari, 2018). Oleh karena itu, untuk mensintesis pengetahuan yang diperoleh dari penelitian-penelitian sebelumnya dan meningkatkan pengetahuan akademis tentang topik tersebut, maka penelitian-penelitian terdahulu tentang budaya keselamatan kerja di industri konstruksi perlu dikaji ulang. Sayangnya, belum ada makalah yang secara khusus mengulas penelitian-penelitian sebelumnya tentang budaya keselamatan di industri konstruksi. Oleh karena itu, makalah ini bertujuan mengkaji dan mengklasifikasikan temuan-temuan utama dari studi budaya keselamatan di industri konstruksi untuk mendeskripsikan budaya keselamatan kerja di industri konstruksi dan mengusulkan agenda penelitian di masa depan.

\section{METODE PENELITIAN}

Dalam usaha mencapai tujuan dari artikel ini, dilakukan tinjauan pustaka yang komprehensif tentang studi budaya keselamatan kerja di industri konstruksi. Kajian ini dimulai dengan mengumpulkan makalah yang diterbitkan dalam peer review jurnal akademik dari enam basis data yaitu Emeraldinsight, ScienceDirect, Google Scholar, Proquest, Springerlink, dan Ebsco dari tahun 2017 sampai dengan 2019. Kami menggunakan kata kunci "Safety Culture" dan "Safety Culture in Construction Industry" untuk mencari artikel yang akan kami tinjau. Artikel yang kami pilih adalah artikel yang membahas budaya keselamatan kerja di industri konstruksi. Kami mengecualikan makalah yang tidak hanya membahas budaya keselamatan kerja tetapi juga budaya perusahaan lainnya, seperti budaya klan dan budaya pasar.

Tabel 1. Penelitian budaya keselamatan kerja di industri konstruksi

\begin{tabular}{lccc}
\hline Budaya Keselamatan Menurut Sektor Industri & 2017 & 2018 & 2019 \\
\hline Konstruksi & 860 & 927 & 958 \\
\hline
\end{tabular}


Artikel yang dipilih, dianalisis dan dikategorikan berdasarkan masalah yang dibahas. Tabel 1 menunjukkan hasil pengelompokan artikel. Hasil penelusuran literatur kami menunjukkan bahwa terdapat 25 makalah yang membahas tentang budaya keselamatan kerja di industri konstruksi. Berdasarkan permasalahan yang dibahas pada artikel, terdapat tiga topik utama yang diselidiki oleh studi mereka, yaitu efektivitas dari penerapan budaya keselamatan kerja di industri konstruksi; proses penerapan budaya keselamatan kerja di industri konstruksi; interpretasi budaya keselamatan kerja pada industri konstruksi.
Berdasarkan tinjauan pustaka pada topik pertama, hasil tinjaun menunjukan temuan yang tidak konsisten terkait efektivitas penerapan budaya keselamatan kerja di industri konstruksi. Beberapa studi mengonfirmasi keefektifitasan dari budaya keselamatan kerja di industri konstruksi (Oswald et al. 2018; Schwatka et al. 2016; van Kampen et al. 2017), sedangkan penelitian lain menemukan kesimpulan yang berlawanan (Fang \& Wu, 2013; He et al. 2012; Zou \& Sunindijo, 2013). Hal ini menunjukkan bahwa efektivitas budaya keselamatan kerja dalam industri konstruksi masih memerlukan kajian empiris lebih lanjut. Tabel 2 memperlihatkan kajian empiris yang dilakukan terkait penelitian budaya keselamatan kerja di industri konstruksi untuk memberikan arah penelitian selanjutnya.

Tabel 2. Penelitian budaya keselamatan kerja di industri konstruksi

\begin{tabular}{|c|c|c|c|c|c|}
\hline Penulis & Metode Penelitian & Sampel & $\begin{array}{c}\text { Efekti- } \\
\text { vitas }\end{array}$ & $\begin{array}{l}\text { Imple- } \\
\text { mentasi }\end{array}$ & $\begin{array}{l}\text { Inter- } \\
\text { pretasi }\end{array}$ \\
\hline Ćetković et al. (2015) & Studi kasus & Sektor konstruksi Montenegrin & $\sqrt{ }$ & $\sqrt{ }$ & \\
\hline Robles et al. (2014) & Studi kasus & Spanish Construction & $\sqrt{ }$ & & \\
\hline Naoum (2016) & Studi literatur & Industri konstruksi UK & $\sqrt{ }$ & & \\
\hline $\begin{array}{l}\text { Sherekar \& Tatikonda } \\
\text { (2016) }\end{array}$ & Metode AHP & Konstruksi India, Pune & $\sqrt{ }$ & $\sqrt{ }$ & \\
\hline Sunindijo (2015) & Survei & $\begin{array}{l}\text { Perusahaan konstruksi kecil, New } \\
\text { South Wales, Australia }\end{array}$ & $\sqrt{ }$ & & $\sqrt{ }$ \\
\hline Machfudiyanto et al. (2017) & Metode Delphi & Perusahaan konstruksi di Indonesia & $\sqrt{ }$ & $\sqrt{ }$ & \\
\hline Zou \& Sunindijo (2013) & Survei & 15 perusahaan konstruksi di Australia & $\sqrt{ }$ & & \\
\hline Bust et al. (2008) & Survei & Industri konstruksi di UK & $\sqrt{ }$ & & $\sqrt{ }$ \\
\hline Saifullah \& Ismail (2012) & Studi literatur & Perusahaan konstruksi di Malaysia & $\sqrt{ }$ & & \\
\hline Goh \& Askar Ali (2016) & Metode simulasi hybrid & Perusahaan konstruksi di Singapore & $\sqrt{ }$ & $\sqrt{ }$ & \\
\hline Lai et al. (2011) & Wawancara and Survei & Proyek konstruksi di US dan Singapore & $\sqrt{ }$ & & \\
\hline Rafuse (2002) & $\begin{array}{l}\text { Safe Work Method } \\
\text { Statement (SWMS) }\end{array}$ & $\begin{array}{l}\text { Dua site Konstruksi komersil di } \\
\text { Australia }\end{array}$ & $\sqrt{ }$ & & \\
\hline Petitta et al. (2017) & Survei & 32 perusahaan konstruksi di italia & $\sqrt{ }$ & & $\sqrt{ }$ \\
\hline Mahmoudi et al. (2014) & Survei & 3 perusahaan konstruksi & $\sqrt{ }$ & & \\
\hline Alarcón et al. (2016) & $\begin{array}{l}\text { Teknik Visual analyses } \\
\text { of graphical information, } \\
\text { statistical analyses, and } \\
\text { classification }\end{array}$ & $\begin{array}{l}1180 \text { perusahaan konstruksi dan } 221 \\
\text { praktisi }\end{array}$ & $\sqrt{ }$ & & $\sqrt{ }$ \\
\hline Senouci et al. (2015) & Wawancara and Survei & Proyek konstruksi Qatari building & $\sqrt{ }$ & & $\sqrt{ }$ \\
\hline Zheng \& Chen (2012) & Evaluasi & Proyek konstruksi jalan tol di China & $\sqrt{ }$ & & \\
\hline Machfudiyanto et al. (2017) & Survei & 100 perusahaan konstruksi & $\sqrt{ }$ & $\sqrt{ }$ & \\
\hline Biggs et al. (2013) & $\begin{array}{l}\text { Wawancara, metode } \\
\text { Delphi }\end{array}$ & $\begin{array}{l}\text { Perusahaan konstruksi besar di } \\
\text { Australian }\end{array}$ & $\sqrt{ }$ & & $\sqrt{ }$ \\
\hline Wu et al. (2016) & Survei & 20 proyek konstruksi di China & $\sqrt{ }$ & & \\
\hline van Ooijen et al. (2019) & Narasi & $\begin{array}{l}\text { Perusahaan konstruksi kecil menengah } \\
\text { di northeastern Netherlands }\end{array}$ & & $\sqrt{ }$ & $\sqrt{ }$ \\
\hline Atombo et al. (2017) & Action Research & Proyek konstruksi di China & $\sqrt{ }$ & & \\
\hline Stiles et al. (2018a) & Wawancara mendalam & 26 Konstruksi rel & $\sqrt{ }$ & & \\
\hline W. Fang et al. (2020) & Studi literatur & 107 artikel antara tahun 2009 dan 2019 & $\sqrt{ }$ & & \\
\hline Bavafa et al. (2018) & Metode Fuzzy Delphi & Proyek konstruksi di Kuala lumpur & $\sqrt{ }$ & & \\
\hline
\end{tabular}




\section{HASIL}

Budaya keselamatan kerja didefinisikan sebagai persepsi individu dari berbagai aspek keselamatan di lingkungan kerja, seperti prosedur keselamatan kerja dan kinerja keselamatan kerja (Clarke, 1999). Sebuah tinjauan dari Neal \& Griffin (2004) pada penelitian perilaku perusahaan menunjukan bahwa efektifitas perilaku perusahaan dipengaruhi oleh beberapa faktor moderasi. Hasil penelitian efektivitas budaya keselamatan kerja yang kontradiktif menunjukkan adanya faktor-faktor pemoderasi dalam penerapan budaya keselamatan kerja pada industri konstruksi. Oleh karena itu, perlu dimasukkan faktor-faktor pemoderasi pada penelitian selanjutnya tentang efektivitas budaya keselamatan kerja pada industri konstruksi yang pada penelitian sebelumnya tidak dibahas secara khusus. Proses implementasi budaya keselamatan kerja di industri konstruksi selengkapnya pada Gambar 1.

Pada aspek metodologi penelitian, peneliti mengkaji efektifitas penerapan budaya keselamatan kerja dengan menggunakan dua metode penelitian yaitu studi kasus dan metodologi survei berdasarkan persepsi praktisi dan pakar. Dalam konteks ini, kami mengamati beberapa masalah. Penelitian dengan metode studi kasus memiliki keterbatasan dalam hal sifat pendekatannya. Diketahui bahwa studi kasus merupakan pendekatan yang berbasis pada konteks strategi perusahaan tertentu yang mengakibatkan sulitnya digeneralisasikan ke dalam konteks yang berbeda. Selain itu, pendekatan studi kasus lebih mengandalkan sumber data yang berasal dari perspektif perusahaan daripada perspektif karyawan. Oleh karena itu, hasil penelitian mungkin tidak benarbenar mencerminkan keberlanjutan penerapan buadya keselamatan kerja di industri konstruksi menurut perilaku karyawan. Sedangkan budaya keselamatan kerja merupakan employee driven satisfaction dimana efektivitas pelaksanaannya akan lebih tepat untuk dinilai dengan perspektif karyawan (Bailey \& Soane, 2012).

Penelitian dengan metode survei juga memiliki beberapa keterbatasan. Pertama, penelitian juga menggunakan data dari perspektif perusahaan daripada perspektif karyawan. Kedua, penelitian sebelumnya hanya menggunakan variabel dependen yaitu budaya perusahaan (Nguyen \& Watanabe, 2017). Sedangkan budaya keselamatan kerja merupakan pedoman bagi perusahaan untuk menjamin kepuasan karyawan, tidak hanya budaya perusahaan (van Ooijen et al. 2019). Oleh karena itu, budaya perusahaan tidak cukup untuk membenarkan efektivitas penerapan budaya keselamatan kerja dalam industri konstruksi. Masalah kedua dalam penelitian budaya keselamatan kerja yaitu proses penerapan budaya keselamatan kerja pada industri konstruksi, beberapa peneliti telah menjelaskan proses yang dialami oleh industri konstruksi dalam menerapkan budaya keselamatan kerja, diantaranya adalah (Ćetković et al. 2015; Goh \& Askar Ali, 2016; Machfudiyanto et al. 2017; Petitta et al. 2017; Rafuse, 2002; Robles et al. 2014; Sawacha et al. 1999; Sherekar \& Tatikonda, 2016; Sunindijo, 2015).

Anteseden Organisasi

\begin{tabular}{|c|c|c|c|}
\hline Budaya Keselamatan Kerja & Determinan & Komponen Budaya & Hasil Budaya \\
\hline $\begin{array}{c}\text { Faktor Organisasi } \\
\text { (Supervisi, desain pekerjaan) }\end{array}$ & $\begin{array}{c}\text { Budaya } \\
\text { Keselamatan Kerja }\end{array}$ & 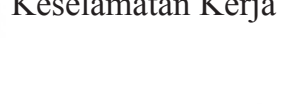 & $\begin{array}{c}\text { Keselamatan } \\
\text { Kerja }\end{array}$ \\
\hline Anteseden Pekerja & $\rightarrow \begin{array}{c}\text { Motivasi \& } \\
\text { pengetahuan } \\
\text { keselamatan } \\
\text { kerja }\end{array}$ & $\begin{array}{c}\text { Kinerja } \\
\text { Keselamatan } \\
\text { Kerja }\end{array}$ & $\begin{array}{c}\text { Luaran } \\
\text { Keselamatan } \\
\text { Kerja }\end{array}$ \\
\hline $\begin{array}{c}\text { Sikap } \\
\text { (komitmen) }\end{array}$ & & & \\
\hline $\begin{array}{l}\text { Perbedaan Individu } \\
\text { (kesadaran) }\end{array}$ & & & \\
\hline
\end{tabular}

Gambar 1. Proses implementasi budaya keselamatan kerja di industri konstruksi 
Penelitian sebelumnya secara umum menunjukkan bahwa ada cara umum dalam menerapkan budaya keselamatan dalam industri konstruksi. Lebih jelasnya, mereka menunjukkan bahwa proses penerapan budaya keselamatan di industri konstruksi terdiri dari 5 bagian seperti terlihat pada Gambar 1 . Meskipun ada hasil yang meyakinkan dari penelitian tentang proses penerapan budaya keselamatan kerja di industri konstruksi, kami mengamati masih ada beberapa masalah yang masih belum jelas terkait topik tersebut.

Pertama, kami mencatat bahwa temuan penelitian sebelumnya hanya berfokus pada langkah penerapan budaya keselamatan kerja. Belum ada penelitian yang mengungkap keterkaitan budaya keselamatan kerja dengan perspektif karyawan. Diketahui bahwa budaya keselamatan kerja hanya digunakan oleh perusahaan sebagai alat untuk melengkapi persyaratan dalam suatu proyek, bukan untuk melindungi karyawan dari bahaya di tempat kerja (Fernández-Muñiz et al. 2017). Kondisi ini akan menjadikan budaya keselamatan kerja memiliki muatan perilaku perusahaan yang berbeda, seperti yang ditunjukkan oleh Schwatka et al. (2016) yang memperlihatkan bahwa meskipun banyak perusahaan yang telah menerapkan budaya keselamatan kerja, namun tingkat kecelakaan kerja di perusahaan tersebut masih tinggi. Hal ini merupakan bukti bahwa penerapan budaya keselamatan kerja hanya menjadi alat untuk mencapai tujuan perusahan dan bukan untuk mensejahterakan karyawan. Oleh karena itu, penting untuk mengaitkan budaya keselamatan kerja berbasis kinerja karyawan dalam penelitian penerapan budaya keselamatan di industri konstruksi. Kedua, hasil penelitian sebelumnya tidak dapat secara jelas menunjukkan perbedaan unik antara proses pelaksanaan budaya keselamatan di industri konstruksi dengan sektor lainnya. Secara umum proses yang ditemukan dalam penelitian sama dengan proses dalam penelitian pada konteks lain. Ketiga, tidak ada penelitian sebelumnya yang menyoroti keterkaitan antara budaya keselamatan kerja dan kinerja perusahaan. Penting untuk memahami hubungan antara budaya keselamatan kerja dan kinerja perusahaan karena literatur budaya keselamatan kerja menunjukkan bahwa penerapan budaya keselamatan kerja akan meningkatkan kinerja perusahaan, terutama dari perspektif keuangan karena dapat mengurangi biaya yang ditimbulkan akibat kecelakaan akibat (Fernández-Muñiz et al. 2017).
Pada aspek metodologi penelitian, semua peneliti melakukan pendekatan studi kasus untuk menyelidiki topik tersebut. Dalam literatur manajemen diketahui bahwa studi kasus adalah pendekatan penelitian berbasis konteks tertentu yang temuan penelitiannya tidak dapat digeneralisasikan ke dalam konteks yang berbeda. Sayangnya, penelitian sebelumnya sebagian besar dilakukan di negara maju. Oleh karena itu, temuan penelitian mungkin tidak dapat digeneralisasikan ke dalam industri konstruksi lain di negara berkembang. Dengan kata lain, perlu dilakukan penelitian tentang proses penerapan budaya keselamatan kerja pada industri konstruksi di negara berkembang.

Selanjutnya, untuk masalah penelitian ketiga yaitu interpretasi budaya keselamatan kerja dalam industri konstruksi, kami hanyamenemukan satu studi pada topik tersebut, yang dilakukan oleh Ek et al. (2014) . Hal ini cukup mengejutkan karena budaya keselamatan kerja menggunakan banyak konsep dan terminologi proyek. Hal ini mungkin menimbulkan beberapa kesulitan dalam memahami implementasi konsep (Demirkesen \& Ozorhon, 2017). Penerapan budaya keselamatan kerja dalam industri konstruksi di Indonesia memerlukan penyesuaian tertentu agar sesuai dengan sifat industri konstruksi di negara berkembang (Stiles et al. 2018b). Akibatnya, interpretasi budaya keselamatan kerja yang berbeda menjadi sulit untuk dihindari.

Penelitian sebelumnya telah menunjukkan bahwa terdapat perbedaan interpretasi tentang bagaimana budaya keselamatan kerja diterapkan dalam suatu perusahaan. Naoum (2016) misalnya, menjelaskan bahwa penerapan budaya keselamatan kerja yang di perusahaan konstruksi di UK mengacu pada standar international yang tetapkan oleh pemerintah untuk melindungi karyawan dari risiko kecelakaan di tempat kerja. Sedangkan Atombo et al. (2017) menerangkan bahwa budaya keselamatan kerja di China merupakan salah satu syarat agar perusahaan dapat mengerjakan proyek konstruksi dengan budget serendah-rendahnya. Dengan demikian, dapat dilihat bahwa penelitian sebelumnya dilakukan berdasarkan analisis dari perspektif perusahaan saja tidak termasuk berdasarkan perspektif karyawan. Oleh karena itu, masih belum jelas mengenai masalah pada interpretasi yang berbeda pada penerapan budaya keselamatan kerja pada level karyawan. Penelitian selanjutnya dapat mencoba untuk fokus pada hal tersebut dan mengaitkannya dengan kinerja perusahaan. 


\section{Implikasi Manajerial}

Studi ini memiliki implikasi besar bagi para pimpinan perusahaan konstruksi di Indonesia mengingat bahwa keselamatan kerja menjadi tolak ukur dari kinerja perusahaan terutama pada industri konstruksi yang memiliki risiko tinggi terjadinya kecelakaan kerja. Studi ini memberi arah kebijakan yang dapat diambil oleh para pimpinan dalam membangun dan menerapkan budaya keselamatan kerja yang efektif yang didasarkan pada perspektif karyawan. Para pimpinann dapat meningkatkan kinerja perusahaan dengan membangun interpretasi yang benar dan menyeluruh pada karyawan serta memaksimalkan praktik budaya keselamatan kerja. Hal ini akan menurunkan kemungkinan terjadinya kecelakaan kerja dan meningkatnya kemungkinan peningkatan kinerja karyawan yang pada akhirnya akan mendorong peningkatan kinerja perusahaan.

\section{KESIMPULAN DAN SARAN}

\section{Kesimpulan}

Kajian literatur yang telah dijabarkan diatas menunjukkan bahwa temuan yang dihasilkan dari penelitian terdahulu mengenai efektivitas penerapan budaya keselamatan kerja dalam industri konstruksi, belum dapatdisimpulkan. Selanjutnya, peneliti mencoba menguji penerapan budaya keselamatan kerja dengan kinerja perusahaan tetapi satu-satunya indikator yang digunakan sebagai ukuran kinerja adalah kepatuhan keselamatan kerja (Petitta et al. 2017) dimana pada penelitian sebelumnya indikator tersebut digunakan untuk mencapai kinerja keselamatan kerja (Behari, 2018).

Lebih lanjut, kinerja perusahaan dianggap setara dengan efisiensi perusahaan yang merepresentasikan sejauh mana suatu perusahaan sebagai suatu sistem sosial dengan sumber daya dan sarana yang terbatas dapat mencapai tujuannya tanpa upaya yang berlebihan dari para anggotanya. Tepret \& Tuna, (2015) menjelaskan bahwa kinerja perusahaan harus dicapai melalui indikator seperti uji coba, evaluasi, efisiensi, efektivitas, dan kualitas. (Oliver, 2017) menambahkan bahwa kriteria yang digunakan untuk menilai kinerja adalah produktivitas. Produktivitas yang dimaksud disini adalah tingkat produktivitas pekerja yang meningkat akibat dari kepuasan kerja yang baik yang dicapai melalui penerapan budaya keselamatan kerja di perusahaan. Semakin tinggi tingkat produktivitas pekerja, dipercaya akan meningkatkan kinerja perusahaan (Nordlöf et al. 2015). Berdasarkan penjelasan tersebut, menjadi penting untuk mengetahui efektifitas penerapan budaya keselamatan kerja dengan menggunakan ukuran perspektif karyawan untuk melihat dampaknya terhadap peningkatan kinerja perusahaan. Oleh karena itu, kami mengusulkan agenda penelitian sebagai berikut: Apakah budaya keselamatan kerja dapat meningkatkan produktivitas pekerja dan memengaruhi kinerja perusahaan dalam Industri Konstruksi?.

Temuan yang tidak konsisten dari penelitian tentang efektivitas budaya keselamatan kerja menunjukkan bahwa diperlukan faktor moderasi (de Castro et al. 2017). Dalam perspektif manajemen stratejik, terdapat dua faktor yang harus diperhatikan yaitu faktor internal dan eksternal (Sigalas, 2015). Faktor internal perusahaan meliputi sumber daya, kapabilitas, dan kompetensi perusahaan sedangkan faktor eksternal terdiri dari lingkungan eksternal perusahaan, termasuk kondisi makro ekonomi dan stakeholders. Literatur menyatakan bahwa faktor-faktor tersebut memengaruhi strategi dan sistem perusahaan yang diterapkan dalam suatu perusahaan (Porter, 1998). Perusahaan dengan sudut pandang ekternal, akan menggunakan strategi cost efficiency untuk memenangkan persaingan pasar yang berarti, perusahaan akan meminimalkan pengeluaran untuk menghemat anggaran termasuk dalam menerapkan budaya keselamatan kerja yang dinilai tidak mendatangkan keuntungan bagi perusahaan. Sebaliknya, perusahaan dengan sudut pandang internal, akan memaksimalkan nilai perusahaan dengan meningkatkan kesejahteraan pekerja melalui penerapan budaya keselamatan kerja yang akan meningkatkan produktivitas mereka yang akan berdampak pada peningkatan kinerja perusahaan. Oleh karena itu, penting untuk mengidentifikasi faktor internal dan eksternal suatu perusahaan yang dapat memengaruhi efektivitas penerapan budaya keselamatan kerja di industri konstruksi. Dengan demikian, kami mengusulkan agenda penelitian berikut ini:

- Faktor internal apa yang memengaruhi efektivitas penerapan budaya keselamatan kerja di industri konstruksi?

- Faktor eksternal apa yang memengaruhi keefektifan penerapan budaya keselamatan kerja di industri konstruksi? 
Kajiankamimenunjukkan bahwa penelitian sebelumnya tentang proses penerapan budaya keselamatan kerja pada industri konstruksi hanya berfokus pada kepatuhan penerapan budaya keselamatan kerja berdasarkan perspektifperusahaan.Lebihlanjut, belumadapenelitian yang mengungkap sudut pandang karyawan terkait budaya keselamatan kerja. Sementara itu, pendekatan yang berbeda terhadap perspektif perusahaan dari budaya keselamatan kerja diharapkan dalam beberapa literatur. Sebagai contoh, (Christian et al. 2009) menyatakan bahwa budaya keselamatan kerja tidak hanya untuk peningkatan kinerjaperusahaan, tetapi juga untuk peningkatan kesejahteraan karyawannya. Oleh karena itu, kami mengusulkan agenda penelitian berikut:

- Bagaimana pendekatan budaya perusahaan dalam penerapan budaya keselamatan kerja di industri konstruksi yang tidak hanya meningkatkan kinerja perusahaan tetapi juga meningkatkan kesejahteraan karyawan?

- Jika ada perbedaan, pendekatan mana yang paling efektifuntuk menerapkan budaya keselamatan kerja dalam industri konstruksi untuk meningkatkan kinerja perusahaan dan juga meningkatkan kesejahteraan karyawan?

- Faktor apa yang memengaruhi pendekatan dalam budaya perusahaan untuk menerapkan budaya keselamatan kerja di industri konstruksi?

Tinjauan kami menunjukkan bahwa penelitian tentang interpretasi budaya keselamatan kerja dalam industri konstruksi masih sangat terbatas. Selanjutnya dilakukan berdasarkan analisis terhadap dokumen pedoman penyelenggaraan Administrasi Kesehatan dan Keselamatan Kerja, bukan berdasarkan persepsi praktisi perusahaan budaya keselamatan kerja. Oleh karena itu, masih belum jelas mengenai masalah pada interpretasi yang berbeda pada pelaksanaan budaya keselamatan kerja. Mengingat hal ini, kami merekomendasikan agenda penelitian berikut:

- Adakah perbedaan interpretasi budaya keselamatan kerja pada praktisi perusahaan?

- Jika ada, faktor apa yang memengaruhi perbedaan tersebut?

Tinjauan kami menunjukkan bahwa penelitian sebelumnya tentang Budaya Keselamatan Kerja di Industri Konstruksi terutama dilakukan di negara-negara maju. Karena negara maju memiliki karakteristik yang berbeda dengan negara berkembang seperti ukuran perusahaan dan peraturan perundangan terkait sistem keselamatan kerja yang berlaku di negara tersebut. Sedangkan, budaya keselamatan juga banyak diterapkan di industri konstruksi di negara berkembang, seperti Malaysia, Vietnam, dan Kamboja (Manu et al. 2018), maka penelitian ke depan juga perlu dilakukan dalam konteks negara-negara berkembang.

\section{Saran}

Mengenai metode penelitian, kami mengusulkan pendekatan penelitian yang berbeda untuk menyelidiki agenda penelitian. Mengenai agenda penelitian pertama, kami mengusulkan penggunaan metodologi survei kepada Top Manager perusahaan konstruksi sebagai responden. Dengan menggunakan perspektif manajer, hasil temuan akan benar-benar mencerminkan persepsi karyawan. Sedangkan variabel dependen dari masalah penelitian yaitu produktivitas karyawan mewakili kinerja karyawan. Selain itu, metodologi survei memberikan validitas eksternal, yang memungkinkan peneliti untuk menggeneralisasi temuan penelitian. Terkait dengan agenda penelitian kedelapan mengenai metode penelitian yang digunakan. Pertama, sebaiknya peneliti melakukan pendekatan studi kasus. Hal ini berdasarkan fakta bahwa penelitian tentang isu tersebut masih langka. Pendekatan studi kasus tepat jika literatur tentang masalah tersebut terbatas. Selain itu, tepat juga jika peneliti ingin mendalami konteks penelitian. Namun, temuan hasil studi kasus tidak dapat digeneralisasi. Oleh karena itu, pada tahap kedua, kami mengusulkan metodologi survei menggunakan perspektif perusahaan untuk memeriksa validitas eksternal dari temuan yang dihasilkan.

\section{DAFTAR PUSTAKA}

Alarcón LF, Acuña D, Diethelm S, Pellicer E. 2016. Strategies for improving safety performance in construction firms. Accident Analysis and Prevention 94:107-118.

Atombo C, Wu C, Tetteh EO, Nyamuame GY, Agbo AA. 2017. Safety and health perceptions in work-related transport activities in Ghanaian industries. Safety and Health at Work 8(2):175182.

Bailey, SoaneE.2012.Thelinkbetweenperceivedhuman resource management practices, engagement and employee behavior : A moderated mediation model. The International Journal of Human Resource Management 24(2):37-41. 
Bavafa A, Mahdiyar A, Marsono AK. 2018. Identifying and assessing the critical factors for effective implementation of safety programsinconstruction projects. Safety Science 106:47-56.

Behari N. 2018. Assessing process safety culture maturity for specialty gas operations: A case study. Process Safety and Environmental Protection 123:1-10.

Biggs SE, Banks TD, Davey JD, Freeman JE. 2013. Safety leaders' perceptions of safety culture in a large Australasian construction organisation. Safety Science 52:3-12.

Bust PD, Gibb AGF, Pink S. 2008. Managing construction health and safety: Migrant workers and communicating safety messages. Safety Science 46(4):585-602.

Ćetković J, Rutešić S, Zarković M, Knežević M, Vatin N. 2015. Primary directions and advancements in competitiveness of montenegrin construction sector. Procedia Engineering 117(1):775-785.

Christian MS, Bradley JC, Wallace JC, Burke MJ. 2009. Workplace Safety: A meta-analysis of the roles of person and situation factors. Journal of Applied Psychology 94(5):1103-1127.

Clarke SG. 1999. Perceptions of organizational safety: implications for the development of safety culture. Journal of Organizational Behavior 20(2):185-198.

de Castro BL, Gracia FJ, Tomás I, Peiró JM. 2017. The Safety Culture Enactment Questionnaire (SCEQ): Theoretical model and empirical validation. Accident Analysis and Prevention 103:44-55.

Demirkesen S, Ozorhon B. 2017. Impact of integration management on construction projectmanagement performance. International Journal of Project Management 35(8):1639-1654.

Ek Å, Runefors M, Borell J. 2014. Relationships between safety culture aspects - A work process to enable interpretation. Marine Policy 44:179186.

Fang D, Wu H. 2013. Development of a Safety Culture Interaction (SCI) model for construction projects. Safety Science 57:138-149.

Fang W, Love PED, Luo H, Ding L. 2020. Computer vision for behaviour-based safety in construction: A review and future directions. Advanced Engineering Informatics 43.

Fernández-Muñiz B, Montes-Peón JM, VázquezOrdás CJ. 2017. The role of safety leadership and working conditions in safety performance in process industries. Journal of Loss Prevention in the Process Industries 50:403-415.

Goh YM, Askar Ali MJ. 2016. A hybrid simulation approach for integrating safety behavior into construction planning: An earthmoving case study. Accident Analysis and Prevention 93:310 318.

He A, Xu S, Fu G. 2012. Study on the basic problems of safety culture. Procedia Engineering 43:245249.

Islam S, Tseng M, Karia N. 2019. Assessment of corporate culture in sustainability performance using a hierarchical framework and interdependence relations. Journal of Cleaner Production 217:676-690.

Lai DNC, Liu M, Ling FYY. 2011. A comparative study on adopting human resource practices for safety management on construction projects in the United States and Singapore. International Journal of Project Management 29(8):10181032.

Machfudiyanto RA, Latief Y, Arifuddin R, Yogiswara Y. 2017. Identification of Safety Culture Dimensions Based on the Implementation of OSH Management System in Construction Company. Procedia Engineering 171:405-412.

Mahmoudi S, Ghasemi F, Mohammadfam I, Soleimani E. 2014. Framework for continuous assessment and improvement of occupational health and safety issues in construction companies. Safety and Health at Work 5(3):125-130.

Manu P, Mahamadu AM, Phung VM, Nguyen TT, Ath C, Heng AYT, Kit SC. 2018. Health and safety management practices of contractors in South East Asia: A multi country study of Cambodia, Vietnam, and Malaysia. Safety Science 107:188 201.

Margaretha M, Saragih S. 2013. Developing New Corporate Culture through Green Human Resource Practice. Prosiding International Conference on Business, Economics, and Accounting; Bangkok, 20 - 23 Mar 2013. Bangkok: The 2013 IBEA.

Naoum SG. 2016. Factors influencing labor productivity on construction sites: A state-of-the-art literature review and a survey. International Journal of Productivity and Performance Management 65(3):401-421.

Neal A, Griffin MA. 2004. Safety climate and safety at work. The Psychology of Workplace Safety:1534. 
Nguyen LH, Watanabe T. 2017. The impact of project organizational culture on the performance of construction projects. Sustainability (Switzerland) 9(5):19-25.

Nordlöf H, Wiitavaara B, Winblad U, Wijk K, Westerling R. 2015. Safety culture and reasons for risk-taking at a large steel-manufacturing company: Investigating the worker perspective. Safety Science 73:126-135.

Oliver JJ. 2017. The impact of strategic transformation on employee productivity. Strategic HR Review 17(1):55-57.

Oswald D, Sherratt F, Smith S, Dainty A. 2018. An exploration into the implications of the 'compensation culture' on construction safety. Safety Science 109:294-302.

Petitta L, Probst TM, Barbaranelli C, Ghezzi V. 2017. Disentangling the roles of safety climate and safety culture: Multi-level effects on the relationship between supervisor enforcement and safety compliance. Accident Analysis and Prevention 99:77-89.

Rafuse RP. 2002. Interference Rejection Properties of Pseudonoise and Frequency-Hopping Systems - a Review. Conference Record - International Conference on Communications 3:259-276.

Robles G, Stifi A, Ponz-tienda JL, Gentes S. 2014. Labor productivity in the construction industry -factors influencing The Spanish construction labor. International Journal of Civil, Architectural, Structural and Construction Engineering 8(10):999-1008.

Saifullah NM, Ismail F. 2012. Integration of Occupational Safety and Health during Preconstruction Stage in Malaysia. Procedia - Social and Behavioral Sciences 35:603-610.

Sawacha E, Naoum S, Fong D. 1999. Factors affecting safety performance on construction sites Factors affecting safety performance on construction sites. International Journal of Project Management 17(5):309-315.

Schwatka NV, Hecker S, Goldenhar LM. 2016. Defining and measuring safety climate: A review of the construction Industryliterature. Annals of Occupational Hygiene 60(5):537-550.

Senouci A, Al-Abbadi I, Eldin N. 2015. Safety improvement on building construction sites in Qatar. Procedia Engineering 123:504-509.

Sherekar V, Tatikonda M. 2016. Impact of factor affecting on labour productivity in construction projects by AHP method. International Journal of Engineering Science and Computing 6(6): 6771-6775.

Sigalas C. 2015. Competitive advantage: the known unknown concept. Management Decision 53(9): 2004-2016.

Stiles S, Ryan B, Golightly D. 2018a. Evaluating attitudes to safety leadership within rail construction projects. Safety Science 110:34 144.

Stiles S, Ryan B, Golightly D. 2018b. Evaluating attitudes to safety leadership within rail construction projects. Safety Science 110:134144.

Sunindijo RY. 2015. Improving safety among small organisations in the construction industry: Key barriers and improvement strategies. Procedia Engineering 125:109-116.

Sutawijaya AH, Nawangsari LC. 2018. The strategic of implementation health and safety to improved performance construction management system (Case in Arcamanic project, Indonesia). International Journal of Engineering and Technology (UAE) 7(2):176-181.

Tepret NY, Tuna K. 2015. Effect of management factor on employee job satisfaction: an application in telecommunication sector. Procedia - Social and Behavioral Sciences 195(0224):673-679.

van Kampen J, van der Beek D, Steijn W, Groeneweg J, Guldenmund F. 2017. Assessing the statistical properties and underlying model structure of fifteen safety constructs. Safety Science 94:208218.

van Ooijen M, van Nistelrooij A, Veenswijk M. 2019. Urgency for safety in construction: Narrative struggles of carpe diem, memento mori, and negotiated safety. Safety Science 113:68-77.

Wu C, Wang F, Zou PXW, Fang D. 2016. How safety leadership works among owners, contractors and subcontractors in construction projects. International Journal of Project Management 34(5): 789-805.

Zheng S, Chen J. 2012. The study of the core concept of safety culture in highway engineering construction projects. Systems Engineering Procedia 4:460-467.

Zou PXW, Sunindijo RY. 2013. Skills for managing safety risk, implementing safety task, and developing positive safety climate in construction project. Automation in Construction 34:92-100. 